\title{
Correction: emergency surgeon: "last of the mohicans" 2014-2016 editorial policy WSES-WJES: position papers, guidelines, courses, books and original research; from WJES impact factor to WSES congress impact factor
}

\author{
Fausto Catena ${ }^{1 *}$, Frederick Moore ${ }^{2}$, Luca Ansaloni ${ }^{3}$, Ari Leppäniemi ${ }^{4}$, Massimo Sartelli ${ }^{5}$, Andrew B Peitzmann ${ }^{6}$, \\ Walt Biffl', Frederico Coccolini ${ }^{3}$, Salomone Di Saverio ${ }^{8}$, Belinda De Simone ${ }^{1}$, Michele Pisano ${ }^{3}$ \\ and Ernest E Moore ${ }^{7}$
}

\section{Correction}

Since the publication of our Commentary [1], we noticed that Dr. Salomone Di Saverio was incorrectly excluded from and the titles of the books and the order of authors was incorrect in References 1 and 2. The correct references are:

1. Di Saverio S, Tugnoli G, Catena F, Catena G, Ansaloni F, Naidoo N: Trauma Surgery Volume 1: Trauma Management, Trauma Critical Care, Orthopaedic Trauma and Neuro-Trauma. Verlag Italy: Springer; 2014. ISBN 978-88-470-5403-5.

2. Di Saverio S, Tugnoli G, Catena F, Catena G, Ansaloni F, Naidoo N: Trauma Surgery Volume 2: Thoracic and Abdominal Trauma. Verlag Italy: Springer; 2014. ISBN 978-88-470-5459-2.

Author details

${ }^{1}$ Emergency Surgery, Maggiore Parma Hospital, Parma, Italy. ${ }^{2}$ Department of Surgery, University of Florida, Gainesville, FL, USA. ${ }^{3}$ General Surgery Department, Papa Giovanni XXIII hospital, Bergamo, Italy. ${ }^{4}$ Department of Abdominal Surgery, University Hospital Meilahti, Helsinki, Finland. ${ }^{5}$ Department of Surgery, Macerata Hospital, Macerata, Italy. ${ }^{6}$ Department of Surgery, University of Pittsburgh School of Medicine, Pittsburgh, PA, USA. ${ }^{7}$ Department of Surgery, Denver Health Medical Center, Denver, CO, USA.

${ }^{8}$ Department of Surgery, Maggiore Hospital, Bologna, Italy.

Received: 17 March 2014 Accepted: 17 March 2014

Published: 3 April 2014

\section{Reference}

1. Catena F, Moore F, Ansaloni L, Leppäniemi A, Sartelli M, Peitzmann AB, Biffl W, Coccolini F, Di Saverio S, De Simone B, Pisano M, Moore EE: Emergency surgeon: "last of the mohicans" 2014-2016 editorial policy WSES- WJES: position papers, guidelines, courses, books and original research; from WJES impact factor to WSES congress impact factor. World J Emerg Surg 2014, 9:14.

\section{doi:10.1186/1749-7922-9-25}

Cite this article as: Catena et al:: Correction: emergency surgeon: "last of the mohicans" 2014-2016 editorial policy WSES-WJES: position papers, guidelines, courses, books and original research; from WJES impact factor to WSES congress impact factor. World Journal of Emergency Surgery 2014 9:25.

Submit your next manuscript to BioMed Central and take full advantage of:

- Convenient online submission

- Thorough peer review

- No space constraints or color figure charges

- Immediate publication on acceptance

- Inclusion in PubMed, CAS, Scopus and Google Scholar

- Research which is freely available for redistribution

* Correspondence: fausto.catena@gmail.com

${ }^{1}$ Emergency Surgery, Maggiore Parma Hospital, Parma, Italy

Full list of author information is available at the end of the article 